\title{
Correction to: Occurrence and Prognostic Value of Perineural Invasion in Esophageal Squamous Cell Cancer: A Retrospective Study
}

Long Zhang, MD', Jinchen Shao, $\mathrm{PhD}^{2}$, Zhichao Liu, MD ${ }^{1}$, Jie Pan, $\mathrm{MD}^{1}$, Bin $\mathrm{Li}, \mathrm{PhD}^{1}$, Yang Yang, $\mathrm{PhD}^{1}$, Yi He, $\mathrm{PhD}^{1}$, Yuchen Han, $\mathrm{PhD}^{2}$, and Zhigang $\mathbf{L i}, \mathrm{PhD}^{1}$

${ }^{1}$ Department of Thoracic Surgery, Section of Esophageal Surgery, Shanghai Chest Hospital, Shanghai Jiao Tong University, Shanghai, China; ${ }^{2}$ Department of Pathology, Shanghai Chest Hospital, Shanghai Jiao Tong University, Shanghai, China

\section{CORRECTION TO: ANNALS OF SURGICAL}

ONCOLOGY (2021). HTTPS://DOI.ORG/10.1245/S10 434-021-10665-Z

During typesetting, errors in the formatting of Table 3 occurred. The original article has been corrected.
Publisher's Note Springer Nature remains neutral with regard to jurisdictional claims in published maps and institutional affiliations.

The original article can be found online at https://doi.org/10.1245/ s10434-021-10665-z.

(C) Society of Surgical Oncology 2021

Published Online: 9 September 2021

Y. Han, PhD

e-mail: ychan@cmu.edu.cn

Z. $\mathrm{Li}, \mathrm{PhD}$

e-mail: zhigang.li@shchest.org 